\title{
Late complications of circumcision
}

\author{
Abdulla Al-Rawi
}

\begin{abstract}
Background/Purpose The aim of this work was to evaluate the late complications after circumcision.
\end{abstract}

Patients and methods A retrospective file review of 45 boys, ( 3 months to 5 years) referred, over the last 5 years (September 2005-September 2010) for circumcision-related complications to pediatric surgery consultation circumcision was performed by health professionals with the use of Plastibell, whereas in others it was performed by local nonmedical personnel. The complications were observed late; usual time for consultation was between 4 and 10 months after circumcision operation.

Results A total of $\mathbf{4 5}$ children were operated for late complications, 16 cases were incomplete circumcision with redundant foreskin, 12 cases were with postcircumcision phimosis, nine cases had foreskin adherent to the glans,

\section{Introduction}

Circumcision is the most common surgical procedure performed in children, usually performed for medical, cultural or religious reasons.

In the Karak city (approximately $140 \mathrm{Km}$, south of Amman, Jordan), the majority of circumcisions are often performed routinely in the neonatal period.

Circumcision is usually performed by health professionals, such as surgeons and general practitioners, or by a local nonmedical personnel, (ritual circumcisers).

\section{Patients and methods}

This study was performed at the paediatric surgery unit, a section of the General Surgery Department at the Karak Government Hospital affiliated to the Mu'tah Medical College. This unit covers a half-million population area.

A retrospective review of the records of patients referred to us for circumcision-related post operative complications over a 5 years period (from Sept. 2005 to Sept. 2010) was done. Charts were designed to collect the following data from files: age at circumcision, method used, age of presentation for post operative complication, nature of the circumcision-related post operative complications and the surgical correction done.

\section{Results}

Forty-five operative procedures were performed to repair complications of circumcision. These procedures were listed in Table 1.

Procedures were variable: release of the adhesions, redo circumcision, correction of concealed penis and meatotomy.

\begin{abstract}
three cases had a completely buried penile shaft (concealed penis), four cases were with meatal stenosis and one case was with scar due to degloving of the penile skin.
\end{abstract}

Conclusion The use of various techniques without proper knowledge and skills results in a significant number of complications that can be avoided if the operation is performed with adequate training in the technique and its postoperative care. Ann Pediatr Surg 7:79-81 (c) 2011 Annals of Pediatric Surgery

Annals of Pediatric Surgery 2011, 7:79-81

Keywords: circumcision, pitfall, complications, management

Faculty of Medicine, Mu'tah University, Karak Government Hospital, Karak, Jordan

Correspondence to Dr Abdulla Al-Rawi, FRCS, Faculty of Medicine, Mu'tah University, Karak Government Hospital, Karak, Jordan

Tel: + 962796410709;

e-mail: abdrawi2002@yahoo.com

Revision circumcision for incomplete circumcision redundant and long foreskin was the most common procedure and was performed in 16 cases (35.6\%) (Fig. 1).

Redo operation, required after the removal of the fibrotic scar in cases of postcircumcision phimosis, was performed in 12 cases $(26.7 \%$ ) (Figs 2 and 3 ).

Release of adhesion was performed in nine cases (20\%), whereas meatotomy was performed in four cases of meatal stenosis (8.9\%) (Fig. 4).

The three cases of concealed penis $(6.7 \%)$ were repaired, whereas the degloving penile skin required the removal of the scar tissue and plastic correction (Fig. 5).

\section{Discussion}

The rate of performing circumcision varies with different countries, racial groups, social levels and religious background.

The most common procedures involve the use of the Gomco clamp, as described by Manson [1] or the Mogen clamp or Plastibell device, used by Kariher and Smith [2].

Successful performance depends on the awareness of the technique and to make the resection of the foreskin at the coronal level. The degree of circumcision can be assist.

In relation to the length of the foreskin that remained after the operation.

The degree of circumcision can be assessed in relation to the length of the foreskin that remained covering the glans after the operation, and the exposure of the coronal sulcus into four types: A, B, C and D (Wynder and Licklider [3]), where A means that the glans is almost completely covered by foreskin, B, C means that the glans is partially covered by foreskin and $\mathrm{D}$ means complete 
removal of the foreskin. The degree of circumcision may also be classified into three grades: Circumcised, Partially Circumcised, and Uncircumcised (Dunn and Buell [4]).

\section{Table 1 Complication and operative procedures}

\begin{tabular}{lcc}
\hline Types of complications & $\begin{array}{c}\text { Number of } \\
\text { cases (\%) }\end{array}$ & Operative procedures \\
\hline $\begin{array}{l}\text { Redundant foreskin incomplete } \\
\text { circumcision (Fig. 1) }\end{array}$ & $16(35.6)$ & Redo circumcision \\
$\begin{array}{l}\text { Postcircumcision phimosis } \\
\text { (Figs. 2 and 3) }\end{array}$ & $12(26.7)$ & $\begin{array}{c}\text { Removing the fibrotic } \\
\text { scar and redo } \\
\text { circumcision }\end{array}$ \\
Preputial adhesions (Fig. 4) & $9(20)$ & $\begin{array}{c}\text { Release from } \\
\text { the glans }\end{array}$ \\
$\begin{array}{l}\text { Meatal stenosis } \\
\text { Buried penis (Fig. 5) }\end{array}$ & $4(8.9)$ & $\begin{array}{l}\text { Meatotomy } \\
\text { Degloving skin }\end{array}$ \\
$\begin{array}{l}\text { Total cases } \\
\text { Totic correction }\end{array}$ \\
\hline
\end{tabular}

Fig. 1

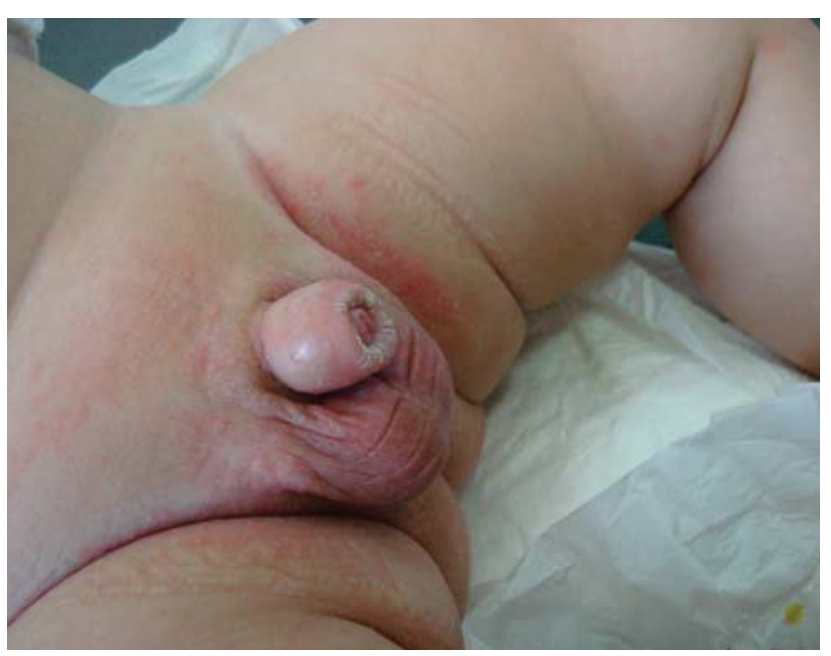

Incomplete circumcision.

\section{Fig. 2}

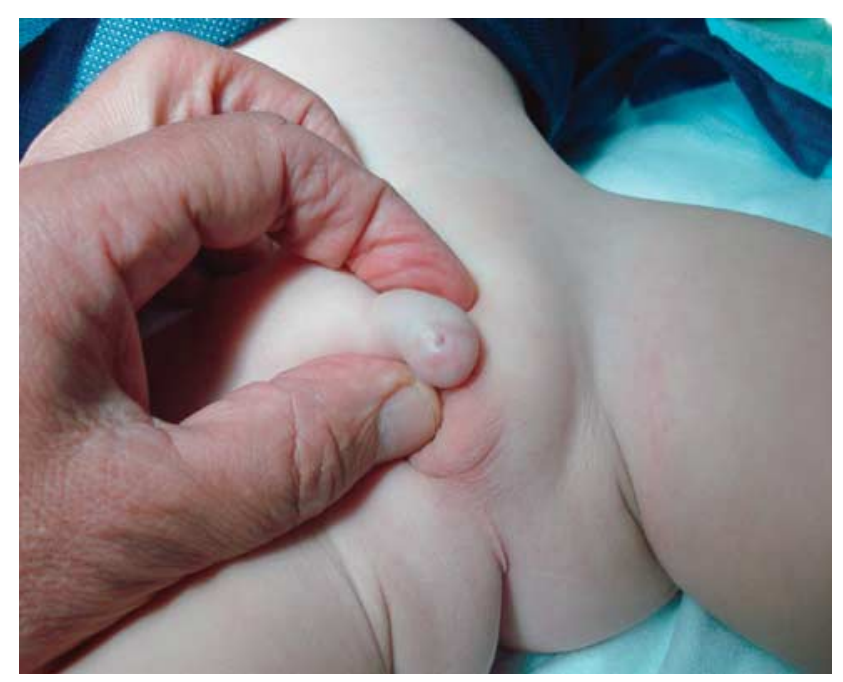

Postcircumcision phimosis.
As the total number of circumcisions performed in our region was not available, and our unit of paediatric surgery is one of several referral centres in the region, and some of these cases are referred to urological and plastic surgery units as well, the incidence of postcircumcision complication is unknown.

Nevertheless, our findings suggest the significant technical problems in performing the circumcision in this region.

The most common indication for revision circumcision was the presence of excess foreskin, (uncircumcized appearance), which was $35.6 \%$ in our report versus $40.1 \%$ in the study carried out by Pieretti et al. [5]. Similarly, Brisson et al. [6] found that redundant foreskin was the most common indication for revision circumcision.

Fig. 3

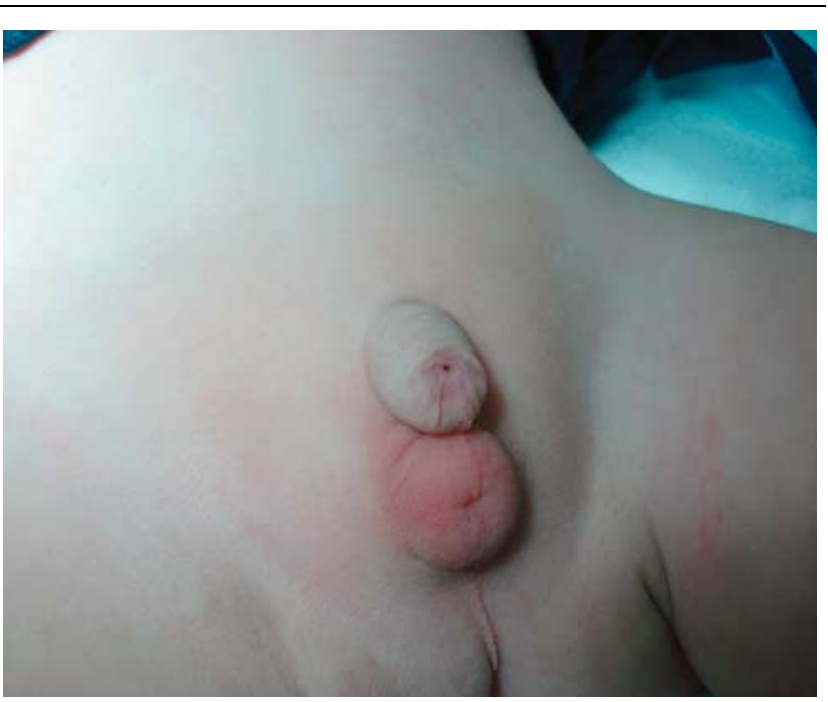

Postcircumcision phimosis.

Fig. 4

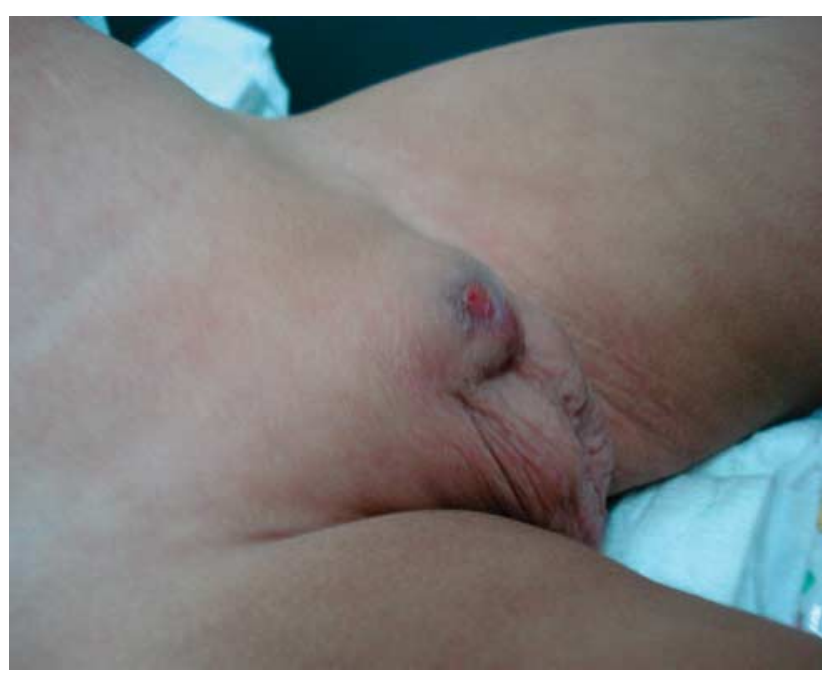

Long foreskin with preputial adhesion. 
Fig. 5

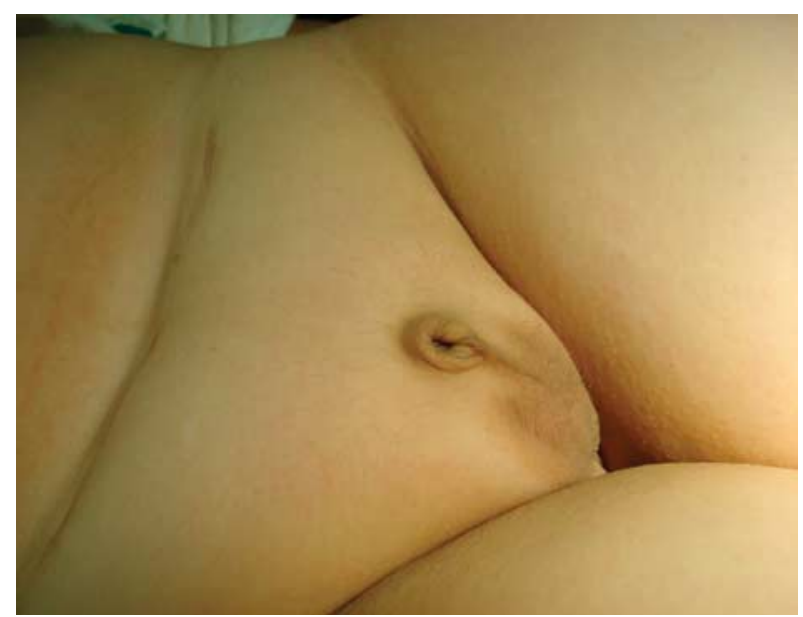

Concealed penis.

Williams and Kapila [7] reported a complication rate of 2-10\%, whereas Leitch [8] showed an early complication of $8 \%$ and a late complication of $7.5 \%$ in his study.

A number of mild cases of complications, such as meatal stenosis and fore skin adhesion, can be easily treated $[9,10]$.

Major complication injuries resulting from instrumentation are retained Plastibell rings, [11] Glans amputation, [12] injuries to the glans and corpus cavernosum, [13] total ablation of the penis [14] and Penile Amputation [15].

The four cases of meatal stenosis that required correction by meatotomy procedure gave a history of meatal ulcer after circumcision operation.

On reviewing the literature, half the cases of meatal stenosis occurred in children with meatal ulceration [16].

Freud [17] considers the meatal orifice to be abnormally small if the anteroposterior diameter is $3 \mathrm{~mm}$ or less.

Williams [18] regarded the stenosis as secondary to ulceration.

Most of the acquired cases of phimosis after circumcision are because of very little foreskin removed at operation, with the infection at the circumcized site that is healed by fibrosis. Twelve cases in this study were treated by resection of the scar and recircumcision.

With regard to the three concealed penises even after circumcision, inadequate dissection of the prepuce and removal of excess penile skin are the causes of this complication; [19] a number of reported complications are due to failure to observe the recommendations for the use of the device.
The most commonly accepted theory is the tendency of the penile shaft to retract into a deep prepubertal fat pad by the reaction of the newly formed circular mucocutaneous union with cicatrization. The puckering scar tissue build up closes over the retracted penis [20].

Trier and Drach [19] suggested that owing to inadequate separation of the inner surface of the prepuce from the glans, coupled with the use of a circumcision device, can lead to the problem of penile concealment.

\section{Conclusion}

Circumcision is a surgical procedure that is associated with potential operative and postoperative complications. Most of these complications result from the use of various techniques without the proper knowledge and skills.

Most of these complications can be prevented by adequate training in the technique and its postoperative care.

\section{References}

1 Manson WW. Circumcision of the newborn; an exact technique for the use of the Gomco clamp. US Armed Forces Med J 1950; 1:586-589.

2 Kariher DH, Smith TW. Immediate circumcision of the newborn. Obstet Gynecol 1956; 7:50-53.

3 Wynder E, Licklider SD. The question of circumcision. Cancer 1960; 13:442.

4 Dunn JE, Buell P. Association of cervical cancer with circumcision of sexual partner. J Nat Cancer Inst 1959; 22:749-764.

5 Pieretti Rafael V, Goldstein Allan M, Pieretti Vanmarcke R. Late complications of newborn circumcision: a common and avoidable problem. Pediatr Surg Int 2010; 26:515-518.

6 Brisson PA, Patel HI, Feins NR. Revision of circumcision in children: report of 56 cases. J Pediatr Surg 2002; 37:1343-1346.

7 Williams N, Kapila L. Complications of circumcision. Br J Surg 1993; 80:1231-1236.

8 Leitch IO. Circumcision: a continuing enigma. Aust Paediatr J 1970; 6:59-65.

9 Kaplan GW. Complications of circumcision. Urol Clin North Am 1983; 10:543-549.

10 Ponsky LE, Ross JH, Knipper N, Kay R. Penile adhesions after neonatal circumcision. J Urol 2000; 164:495-496.

11 Datta NS, Zinner NR. Complication from Plastibell circumcision ring. Urology 1977; 9:57-58.

12 Gluckman GR, Stoller ML, Jacobs MM, Kogan BA. Newborn penile glans amputation during circumcision and successful reattachment. J Urol 1995; 153 (3 Pt 1):778-779.

13 Cetinkaya M, Saglam HS, Beyribey S. Two serious complications of circumcision: case report. Scand J Urol Nephrol 1993; 27:121-122.

14 Gearhart JP, Rock JA. Total ablation of the penis after circumcision with electrocautery: a method of management and long-term followup. J Urol 1989; 142:799-801.

15 Audry G, Buis J, Vazquez MP, Gruner M. Amputation of penis after circumcision penoplasty using expandable prosthesis. Eur J Pediatr Surg 1994; 4:44-45.

16 Patel H. The problem of routine circumcision. Can Med Assoc J 1966; 95:576-581.

17 Freud P. The ulcerated urethral meatus in male children. J Pediatr 1947; 31:131-141.

18 Williams DI. Urology in childhood. Encyclopedia of Urology. Berlin: Springer-Verlag; 1958. p. 244.

19 Trier WC, Drach GW. Concealed penis: another complication of circumcision. Am J Dis Child 1973; 125:276-277.

20 Talarico RD, Jasaitis JE. Concealed penis: a complication of neonatal circumcision. J Urol 1973; 110:732-723. 